(not immediate) successor Darius, and of the other Achæmenians. The absence of 'devá' in any of its forms, and the use of 'baga' for 'god' in these last (sculptures), coincide with the very striking inversion, or perversion, of the (otherwise) Indogermanic name for God, which (perversion) is so very prominent in the Avesta and in all (?) later Persian literature. There (in this Persian lore), as some unaccustomed readers may need to be reminded, it is the name for 'demon,' as against all (?) non-Iranian Indogermanic usage; yet recall the vulgarism 'Deuce.' 1

But if the absence of devá from the Behistūn Inscriptions points to this perversion of the term in Iran, this perversion may be only in the course of development there upon the Darius Inscriptions; that is to say, if C. and D. had no reluctance in using its equivalent 'Heaven-God' in the recorded Edicts. Not so certainly would this be true of the later successors of Darius, whose inscriptions likewise avoid 'devá.' The farther they were separated by time from Cyrus, the more significant their disuse of the word becomes as agreeing with the later perversion. Notice that Cyrus's Edict uses 'Heaven-God' of Yahveh; see also the devout expressions everywhere upon all the Achæmenian Inscriptions which so closely resemble the related scriptural passages.Yours, etc.,

L. H. Mills.

\title{
11. Ignazio Danti and his Maps.
}

To the Editor of the Jounal of the Royal Asiatie Soeicty.

SIR,-In connection with Mr. Beveridge's letter on this subject in the July number, it may be of interest to mention that Professor G. Uzielli refers at some length to Danti's geographical and other work in the course of a discussion on the Toscanelli-Columbus correspondence in the Bolletino of the Italian Geographical Society for 1889, giving besides references to other Italian works which treat fully of Danti's

1 Or is Deuce not 'Zeus,' but Iranian 'Deva(s)'? 
career; while a facsimile reproduction of his map of Perugia, drawn in 1577, appears in the same journal for April-May last, accompanied by letterpress by Professor A. Bellucci. M. Thomassy also, in his "Papes Géographes," published in 1852-53 in the Nouvelles Annales des Voyages, described the maps painted on the walls of the 'Logge di Raffaelo' in the Vatican, in part the work of Ignazio Danti, who at the time of their execution was cosmographer to Pope Gregory XIII. Both Uzielli and Thomassy refer to their intention of recurring elsewhere to the subject of Danti and his work, but I have been unable to find whether the intention was ever carried out. Notices of the padre are to be found in various biographical dictionaries, besides the "Biographie Universelle," though less attention has been paid to him by modern writers on historical geography than to many of his contemporaries. He is not mentioned, e.g., by Nordenskiöld in his "Facsimile Atlas" or "Periplus," nor by Uzielli in his section of the "Studi Bibliografici e Biografici," published by the Italian Geographical Society on the occasion of the Second and Third International Geographical Congresses; while Marinelli's "Geografia dei Padri della Chiesa" deals principally with geographical speculations of an earlier date. It is to be remarked, however, that Danti's work as a cartographer does not seem to compare, for originality, with that of other Italian geographers of his time, Gastaldi for instance. The great resemblance of the Vatican maps to those in Ruscelli's Italian version of Ptolemy (themselves largely copied from Gastaldi's in the first Italian edition of 1548) was pointed out by Thomassy, while as regards the mapping of Bengal, the places referred to by Mr. Beveridge all occur on Gastaldi's “Tertia Pars Asiæ" (1561), of which a facsimile was given by Nordenskiöld in his "Periplus." The 1548 map of India by Gastaldi naturally showed a less advanced stage of knowledge, though itself an improvement on its predecessors. The earlier charts, like Cantino's and Canerio's (1502), though still more rudimentary, were themselves much in advance, as regards the delineation of the 
Indian Peninsula, of the more or less speculative productions in vogue in their time. Igaazio Danti's name, it may be observed in conclusion, has quite recently been once more brought into notice in connection with the ToscanelliColumbus controversy; M. Vignaud ("Toscanelli and Columbus," English edition, 1902, p. 44) branding as a downright forgery the erroneous statement regarding the correspondence of the two famous men which found its way into his 1571 edition of the "Sphæra Mundi" of Sacrobosco.

1, Savile Row, $W$.

Edward Heawood. August 7th, 1903. 